\title{
FAKTOR RISIKO PARITAS TERHADAP PERDARAHAN POSTPARTUM PADA IBU BERSALIN
}

\author{
Ayuni Marya Safita ${ }^{1^{\star}}$, A.Fahira Nur ${ }^{2}$ \\ ${ }^{1}$ Mahasiswa Kebidanan STIKES Widya Nusantara Palu \\ ${ }^{2}$ Bagian Kebidanan STIKES Widya Nusantara Palu \\ *E-mail : ayunimaryasafita@gmail.com
}

Perdarahan postpartum adalah perdarahan yang melebihi $500 \mathrm{ml}$ setelah bayi lahir Bahaya perdarahan postpartum yaitu terjadinya anemia yang dapat memperlemah keadaan pasien, menurunkan daya tahan tubuhnya, dan menjadi faktor predisposisi terjadinya infeksi nifas. Komplikasi perdarahan postpartum segera berupa syok hemoragi (hipovolemik) dan kematian dapat terjadi akibat perdarahan yang tiba-tiba dan perdarahan berlebihan. penyebab perdarahan postpartum yaitu hipertensi, pre eklampsi, eklampsi, anemia berat, polihidramnion, grande multipara, dan persalinan lama. Perdarahan post partum juga dapat disebabkan oleh faktor langsung: Atonia Uteri, Perlukaan jalan lahir, terlepasnya sebagian plasenta dari uterus, tertinggalnya sebagian dari plasenta. Sedang faktor resiko perdarahan post partum adalah usia, paritas, anemia dan jarak lahir. ${ }^{1,3}$

Berikut ini penulis akan membahas tentang faktor risiko perdarahan postpartum terhadap paritas pada ibu bersalin.

\section{Tinjauan tentang paritas}

Paritas adalah keadaan wanita berkaitan dengan jumlah anak yang dilahirkan. Paritas yang tinggi akan berdampak pada timbulnya berbagai masalah kesehatan baik bagi ibu maupun bayi yang dilahirkan. Kehamilan dan persalinan yang berulang-ulang menyebabkan kerusakan pembuluh darah di dinding rahim dan kemunduran daya lentur (elastisitas) jaringan yang sudah berulang kali diregangkan kehamilan, ${ }^{1,4}$

Kehamilan dalam kelompok grande multipara sering disertai 
penyulit-penyulit seperti kelainan letak, perdarahan antepartum, perdarahan post partum dan sebagainya karena keelastisan otot-otot rahim berkurang sehingga menyebabkan atonia uteri, sedangkan Primipara adalah wanita yang pernah mengandung yang melahirkan fetus mencapai berat 500 gram atau umur gestasional $20 \mathrm{mg}$, tanpa tergantung apakah anak itu hidup pada saat dilahirkan, dan apakah kelahiran tunggal atau kembar, Multipara adalah seorang perempuan yang telah hamil 2 kali atau lebih yang menghasilkan janin hidup, tanpa memandang apakah anak itu hidup saat lahir. ${ }^{1}$

\section{Tinjauan tentang paritas}

Paritas berhubungan dengan beberapa faktor yaitu sering melahirkan maka kemungkinan ditemui keadaan kesehatan terganggu, anemia, kurang gizi, kekendoran dinding perut (tampak perut ibu menggantung) kekendoran dinding rahim, sedangkan bahaya yang dapat terjadi kelainan letak, robekan rahim pada kelainan letak lintang, persalinan lama dan perdarahan pasca persalinan (post partum). ${ }^{2}$

Perdarahan post partum terhadap paritas akan berdampak yang di sebabkan oleh kelahiran yang banyak, sehingga terjadi perdarahan $500 \mathrm{cc}$ atau lebih setelah kala III selesai / setelah plasenta lahir, yang mengakibatkan paisen mengalami keadaan umum menjadi lemah, yaitu denyut nadi menjadi cepat dan lemah, tekanan darah menurun, pasien berubah pucat dan dingin, napasnya menjadi sesak. selain itu, hubungan paritas tersebut dengan perdarahan post partum akan berdampak kepada bayinya yang mungkin akan di alami bayi yaitu mengalami berat badan lahir rendah. ${ }^{4}$

\section{Tinjauan tentang risiko Paritas terhadap perdarahan post partum}

Paritas adalah keadaan melahirkan anak baik hidup ataupun mati, tetapi bukan aborsi, tanpa melihat jumlah anaknya. Dengan demikian, kelahiran kembar hanya dihitung sebagai satu kali paritas. ${ }^{4}$

Perdarahan sangat berhubungan dengan paritas karena kelahiran 
yang berulang-ulang menyebabkan kerusakan pembuluh darah di dinding rahim dan kemunduran daya lentur (elastisitas) jaringan yang sudah berulang kali diregangkan kehamilan sehingga cenderung timbul kelainan letak ataupun kelainan pertumbuhan plasenta dan pertumbuhan janin sehingga melahirkan bayi berat badan lahir rendah. ${ }^{4}$

Angka Kematian Ibu (AKI) dan perinatal tersebut dapat di cegah dengan meningkatkan pelayanan kesehatan terutama meningkatkan upaya pengawasan ibu hamil sehingga dapat mendeteksi lebih dini keadaan-keadaan yang mengandung resiko kehamilan dan persalinan baik bagi ibu maupun janin. Dengan demikian dapat diharapkan meningkatkan status kesehatan ibu dan bayi sehingga dapat mewujudkan salah satu program pembangunan nasional yaitu meningkatkan kualitas Sumber Daya Manusia (SDM). ${ }^{2}$ 


\section{DAFTAR PUSTAKA}

1. Ika Fitria Elmeida, I Gusti Ayu Mirah Widhi Sastri (2014). Analisis Determinan Perdarahan Post Partum Di Rumah Sakit. Jurnal Keperawatan, Volume 5, No. 2, Oktober 2014: http://ejurnal.poltekkestjk.ac.id/index.php/JKEP/article/view/283 di akses pada tanggal 13 oktober 2019

2. Etika Desi Yogi, Sinta Ayu Setiawan, Sri Dwi Hastuti (2018). Hubungan Paritas Dengan Kejadian Perdarahan Pada Ibu Post Partum Di Bps Ny. N Di Desa Klagen Serut Kecamatan Jiwan Madiun. Jurnal Delima Harapan, Volume 5 Nomor 2, 2018:

http://jurnal.akbidharapanmulya.com/index.php/delima/article/view/55 di akses pada tanggal 13 oktober 2019

3. Yuliawati1, Yetti Anggraini (2015). Hubungan Riwayat Pre Eklamsia, Retensio Plasenta, Atonia Uteri Dan Laserasi Jalan Lahir Dengan Kejadian Perdarahan Post Partum Pada Ibu Nifas. Jurnal Kesehatan, Volume VI, Nomor 1, April 2015, hlm 75-82 :

https://www.jurnal.umsb.ac.id/index.php/menarailmu/article/view/87 di akses pada tanggal 13 oktober 2019

4. A.Fahira Nur, Abd. Rahman, Herman Kurniawan (2019). Faktor Risiko Kejadian Perdarahan Postpartum Di Rumah Sakit Umum (Rsu) Anutapura Palu. Jurnal Kesehatan Tadulako Vol. 5 No. 1, Januari 2019 : 1-63: http://jurnal.untad.ac.id/jurnal/index.php/HealtyTadulako/article/view/126

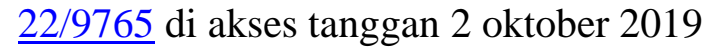

